\title{
GENOMICS OF ACETYLCHOLINESTERASE (AChE) ENZYME AND ITS RELATED RNA CONTENT IN THE BRAIN OF RATTUS NORVEGICUS: A PROSPECTIVE STUDY
}

\author{
Rajesh B ${ }^{1}$, Ramesh B ${ }^{2}$, Rajkiran Reddy B ${ }^{3}$, Vimala devi N ${ }^{4}$, Gayathri KB ${ }^{5}$, Bhargav PRK ${ }^{* 6}$. \\ ${ }^{1}$ Assistant Professor of Anatomy, Mediciti Institute of Medical Sciences, Hyderabad, India. \\ ${ }^{2}$ Assistant Professor of Biochemistry, Mediciti Institute of Medical Sciences, Hyderabad, India. \\ ${ }^{3}$ Senior Research Associate, SMART, Sunshine Hospitals, Hyderabad, India. \\ ${ }^{4}$ Physician Assistant and Research Scholar, Endocare Hospital, Vijayawada, India. \\ ${ }^{5}$ Associate Professor of Gynaecology, PSIMS, Vijayawada, India. \\ ${ }^{* 6}$ Consultant Endocrine and Metabolic Surgeon, Endocare Hospital, Vijayawada, India.
}

\section{ABSTRACT}

\begin{abstract}
Inhibition of acetylcholinesterase (AChE), the metabolizing enzyme of acetylcholine is evolving as the most important therapeutic target for development of cognitive enhancers. However, AChE activity in brain has not been properly evaluated on the basis of sex. In the present study, AChE expression was investigated in different brain areas of cerebrum and cerebellum in male and female Rattus norvegicus. On comparing male and female genders, increased AChE activity was seen in cerebrum and cerebellum of female Rattus norvegicus. However, no significant change in AChE activity was found between cerebrum and cerebellum within the same male and female. Thus it appears that sex alters AChE activity in different brain regions (G4 isoform) that may vary in male and female. Sequence analysis revealed that highest divergence was found in between male cerebrum and female cerebrum (11.9) and least divergence was found in between male cerebellum and female cerebellum (6.4) with control AChE NM_EF534897

KEY WORDS: Acetylcholinesterase, Physiology, Invertebrates, Vertebrates, Cerebrum.
\end{abstract}

Address for Correspondence: Dr. PRK Bhargav MS, MCh, FACS, FIMSA, FAIS, Consultant Endocrine and Metabolic Surgeon, Director and Associate Professor of Endocrine Surgery, Endocare Hospital, Vijayawada, India - 520002, Phone No: +91-866-6617633; +91-9490130798 www.drbhargav.org; endoanswers@gmail.com

\begin{tabular}{|c|c|c|}
\hline \multicolumn{3}{|c|}{ Access this Article online } \\
\hline \multirow{2}{*}{$\begin{array}{l}\text { Quick Response code } \\
\text { DOI: } 10.16965 / \text { ijar.2017.138 }\end{array}$} & \multicolumn{2}{|c|}{$\begin{array}{l}\text { Web site: International Journal of Anatomy and Research } \\
\qquad \text { ISSN 2321-4287 } \\
\text { www.ijmhr.org/ijar.htm }\end{array}$} \\
\hline & $\begin{array}{l}\text { Received: } 06 \text { Feb } 2017 \\
\text { Peer Review: } 06 \text { Feb } 2017 \\
\text { Revised: None }\end{array}$ & $\begin{array}{l}\text { Accepted: } 03 \text { Apr } 2017 \\
\text { Published (O): } 30 \text { Apr } 2017 \\
\text { Published (P): } 30 \text { Apr } 2017\end{array}$ \\
\hline
\end{tabular}

\section{INTRODUCTION}

Acetylcholinesterase (AChE) is one of the most efficient enzymes of nervous system which is concentrated at the cholinergic synapses and at neuromuscular synapses where it rapidly hydrolyses the neurotransmitter acetylcholine (Ach) in to choline and acetate thus playing a vital role in cholinergic neurotransmission. The term acetylcholinesterase was introduced in 1949 by Augustintion and Nachmansohn for specific cholinesterase capable of hydrolyzing acetylcholine faster than other esterases. In 1964 the commission of enzymology recommended the name "Acetylcholinesterase" 
(Acetylcholine Acetyl hydrolase 3.1.1.7) for a true and specific cholinesterase. The distribution of the enzyme in the central and peripheral nerve tissues of different vertebrates demonstrates a high range of variation [1-13]. It has been noted to be localized in non neuronal tissues and Glial cells also $[14,15]$. The enzyme also exhibits molecular diversity with its six different molecular forms and structural dynamics which facilitates its affinity and action with various legends [16-17]. In addition, AChE is considered to play several non classical roles independent of its catalytic function i.e. hydrolysis of Ach. These classical and non classical roles of AChE illustrate adequacy about its wide occurrence in neuronal and non neuronal tissues [18-20]. AChE is widely distributed; it occurs in the central (CNS) and peripheral nervous systems (PNS), and the motor end-plates of the skeletal muscle and the electric organ, but it is also found in many other tissues and in erythrocytes. Therefore such a wide distribution and various functions, molecular forms, structural dynamics etc. of AChE provide adequate base to recall it a versatile enzyme, a detailed knowledge of which, might help to design specific drugs to combat various neurodegenerative diseases associated with this enzyme. In this context, we set up to study the distribution, structure of AChE gene and related RNA in neuronal tissues of invertebrate animals

\section{MATERIALS AND METHODS}

This prospective study was conducted in Anatomy department of a tertiary care teaching medical school in South India. The study was approved by institutional ethical committee. We ensured that study complied with biomedical ethics guidelines for animal experimentation as laid down by Indian council of Medical Research (ICMR). Rattus norvegicus male and female weighing an average $108 \pm 26$ (90-180 grams) were purchased from a local supplier and transported live to the laboratory in aerated tanks. During the acclimatization period, the Rattus norvegicus. were fed daily (Safe feed 7711, Charoen Pokphand Foods PCL, Thailand) weighing about $1 \%$ of the body weight, and were then fasted for 24 hours before the experiment. They were sacrificed, the brain was rapidly removed, weighed, and dissected for RNA extraction and sequencing the brain was rapidly removed for RNA extraction followed by reverse transcription and fold induction of gene expression between AChE and 28S rRNA genes, and were then analysized by PCR and Gel analysis.

RNA isolation: Total RNA was extracted from the brain of house lizard using RNeasy Mini Kit (QIAGEN GmbH, Germany), according to the manufacturer s instructions. RNA was analyzed in $1 \%$ agarose gel, containing ethidiumbromide and visualized with UV light. The $1 \mathrm{~Kb}$ DNA ladder plus and 100 bp DNA ladder plus (Fermentas, USA) was used as molecular marker.

AChE cDNA synthesis and Sequence Analysis: Reverse transcription-polymerase chain reaction (RT-PCR): Complementary DNA (cDNA) was synthesized by using First Strand cDNA Synthesis kit for PCR thermo scientific, according to the manufacturer s instructions. PCR amplification used degenerate primers. Primers of $A C h E$ gene (F-5 GGGCTCCTACTTTCTGGTTTAC $3 \sim \mathrm{R}-5$ AGGTTCAGGCTCACGTATTG 3) designed in conserved region of chick from GENBANK using CODEHOP program.

For the PCR reaction, $4 \mathrm{HI}$ of cDNA from each synthesis were added to $7 \mathrm{HI}$ of "2X PCR master mix containing 10X PCR buffer, $10 \mathrm{mM}$ dNTP, 25 $\mathrm{mM} \mathrm{MgCl} 2,5 \mathrm{U}$ of Taq DNA polymerase (Fermentas, USA). Twenty HM of each pair of the primers was added, and the final volume was adjusted to $14 \mathrm{HI}$ with nuclease free water. The mixtures were denatured at $94^{\circ} \mathrm{C}$ for $3 \mathrm{~min}$. Thirty five cycles of PCR were carried out, with denaturation at $94^{\circ} \mathrm{C}$ for $45 \mathrm{sec}$, annealing at $57^{\circ} \mathrm{C}$ for $30 \mathrm{sec}$, and extension at $72^{\circ} \mathrm{C}$ for $1 \mathrm{~min}$, followed by a final extension period of $5 \mathrm{~min}$. PCR products were analyzed by electrophoresis on $1 \%$ agarose gels stained with GelStar Nucleic Acid Gel Stain (Cambrex Bio Science Rockland, Inc.).

PCR products were cloned into the PGEMT plasmid vector (Promega) and sequenced using forward and reverse primers. Sequencing was performed with the Big DyeTM Terminator Cycle Sequencing Ready Kit, version 3.0 (ABI PrismTM, Perkin Elmer) and an ABI 3700 Applied Biosystems Model automated DNA sequencer. Nucleotide sequences of NWS were analyzed by BLASTN to search for similarities, and sequence 
alignments was performed with CLUSTAL W (Megalign program, DNASTAR Inc., Madison, WI).

\section{Quantitative assessment of RNA by methyl} green-pyronin staining: The tissues are fixed in Methacarn solution (methanol: chloroform: glacial acetic Acid = 6:3:1) fixatives for 4 hours for fixation, and then followed by routine histological processing. The 5 to 6 um sections are taken for all tissues and stained with MGP (methyl green pyronin). The Number of RNA granules are estimated by image analysis by used software IMAGE pro 6.2.

Stastical analysis: ACHE gene Nucleotide sequences were analyzed by BLASTN to search for similarities, and sequence alignments was performed with CLUSTALW (Megalign program, DNASTAR Inc., Madison, WI). Also analysed methyl green-pyronin staining of RNA granules by image pro 6.2 software.

\section{RESULTS}

AChE cDNA sequences: AChE cDNA sequence was used to investigate difference in male and female cerebrum and cerebellum. The ORF of AChE is comprised of 543 nucleotides (GenBank accession number NM_172009.1), showing significant nucleotide similarity $82.2 \%$ and $81.4 \%$ respectively with Rattus norvegicus male cerebrum and cerebellum whereas $84.1 \%$ with female cerebrum and cerebellum AChE Figure 1. Peptide sequences of AchE are shown in Figure 2. The highly divergent regions between the AChE sequences when compare with standard sequence are found in male cerebrum where as when compare with male cerebellum, female cerebrum, female cerebellum was less significant, But when compare with male and female cerebrum and cerebellum, the highest divergence was found in between male cerebrum and female cerebrum and least divergence was found in between male cerebellum and female cerebellum (Figure 3).

Expression of AChE gene: Expression of Acetylcholinesterase (AChE) was significantly more in female cerebrum and cerebellum when compare with male cerebrum and cerebellum (Figure 4). Also, it was found that Methyl green-pyronin staining on Rattus norvegicus brain regions shows more RNA granules in female cerebrum and female cerebellum (Figure 5).

Fig. 1: Alignment of nucleotide sequences of Rattus norvegicus AChE from male and female cerebrum and cerebellum with AChE NM_172009.1 Boxes residue differ from the consensus.

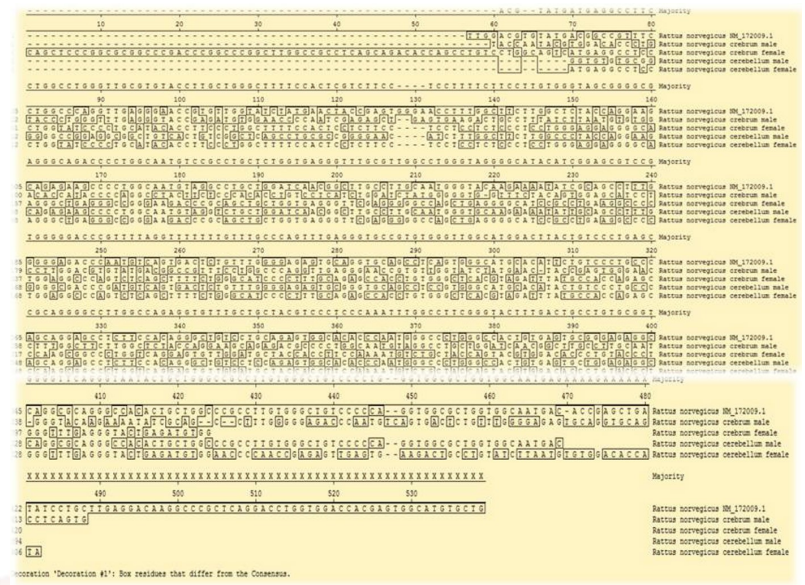

Fig. 2: Alignment of peptide sequences of Rattus norvegicus AChE from male and female cerebrum and cerebellum with AChE NM_172009.1 Boxes residue differ from the consensus.

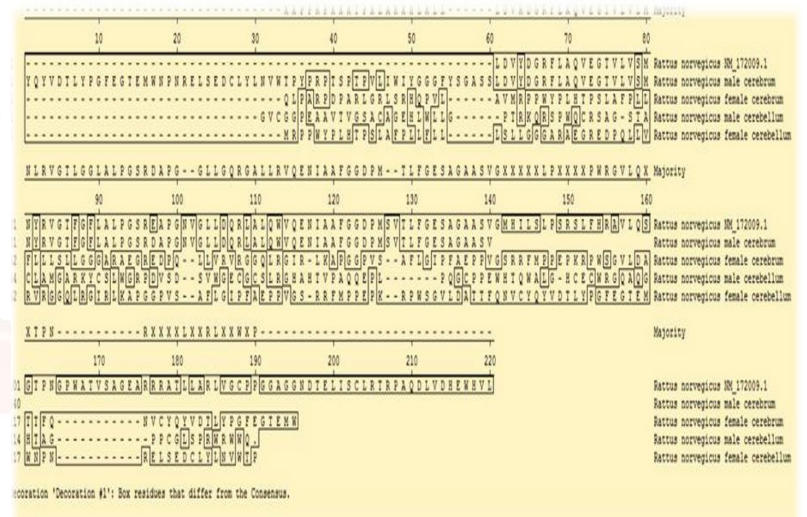

Fig. 3: Percentage identity and divergence of Rattus norvegicus AChE NM_172009.1 nucleotide and amino acid sequences from and Rattus norvegicus AChE of male and female cerebrum and cerebellum.




Fig. 4: Electrophoretogram of Acetylcholinesterase ( AChE) (A) Lane 1,2,3,4 Female cerebrum; Lane 5,6,7.8 Male cerebrum (B) Lane 1,2,3,4 Female Cerebellum; Lane 5,6,7,8 Male Cerebrum.(1 kb ladder marker shown in middle lane). The PCR product size is $338 \mathrm{bp}$.
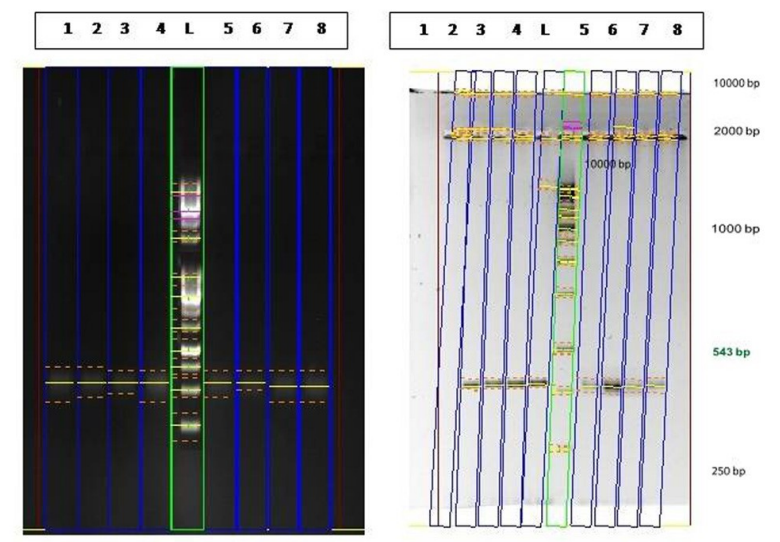

Fig. 5: Methyl green-pyronin staining on Rattus norvegicus brain regions (A) Female Cerebrum showing maximum numbers of RNA granules in comparison with male cerebrum (B) whereas again RNA granules are more in female cerebellum (C) than that seen with male cerebellum (D) (Magnification $40 \mathrm{X}$ ).
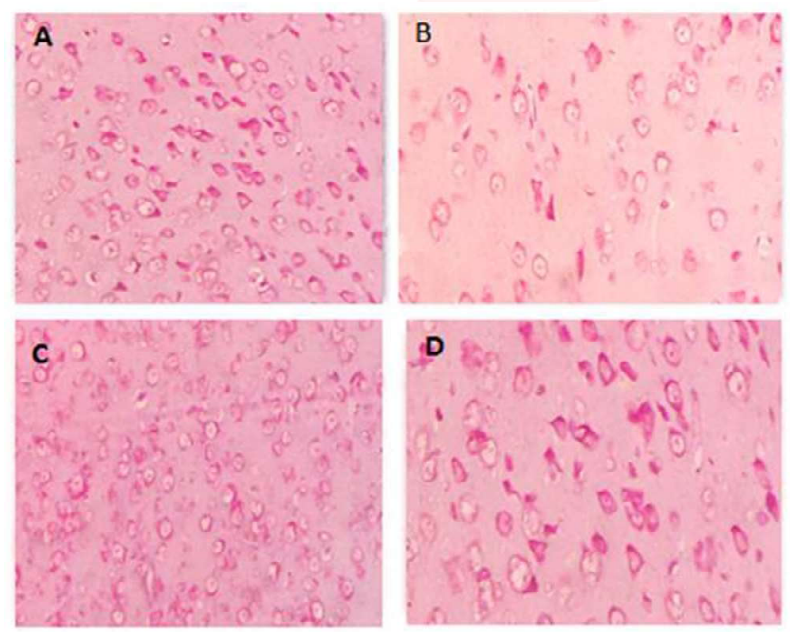

\section{DISCUSSION}

AChEs have so far been identified in different tissues of most vertebrates and more than 20 invertebrate animals [21-24]. For instance, AChE activity has been detected in erythroid cells [25], brain [26], muscle [26], liver [27], kidney [28] and lungs [29] of vertebrates, It was also detectable in different tissues of invertebrates [30-34], such as in the gills, mantle and haemolymph of mollusc [30,31,35], the eye and brain of arthropod [35], and the head of nematode $[33,34]$. There is a great difference in the amino acid sequence of AChEs from different animal, and it even varies greatly among the different tissues of the same organism [17-33]. All the AChEs share some conserved structural features responsible for their catalysis function. For example, an active site triad (Ser, Glu and $\mathrm{His}$ ) exist in all the reported AChEs, and the three residues form a plannar array at the bottom of a deep and narrow gorge, which closely resembles the catalytic triad of other $a / b$ hydrolase fold family proteins [36 ].

Acetylcholinesterase (AChE; EC 3.1.1.7) in vertebrates was involved in cell development and maturation [37], neuronal development and nerve regeneration [38] and inflammation modulation [39]. AChE had also been identified in most invertebrates, including mollusc [31], arthropoda [40], platyhelminthes [41], annelida [42] and nematoda [43]. AChE was also reported to be influencing many physiological behaviors in these invertebrates, including locomotion [43, $44,45]$, feeding $[43,44]$, egg laying [43], male mating [43], embryo development [46] and digestive activity [31].

However, the immunomodulation, genomics and proteomics of AChE is still unclear in invertebrates. All the above literature evidence on AchE, enthused us to embark on this ambitious study to define structure, topography, influence of gender on distribution of neuronal AchE and finally to look for functional heterogeneity of AChE. In the present study, an AChE gene was studied in male and female galus galus cerebrum and cerebellum. The deduced protein of AChE (NM_205418.1) was composed of 118 amino acids, and it shared $94.6-97.2 \%$ identity with other AChEs of cerebrum and cerebellum of male and female.

The importance of AChE in body homeostasis is underscored by the fact that they are the targets of some of the most potent toxins including insecticides, snake venom and chemical weapons [47]. Inhibition of acetylcholinesterase (AChE)-metabolizing enzyme of acetylcholine, is presently the most important therapeutic target for development of cognitive enhancers. However, AChE activity in brain has not been properly evaluated on the basis of sex. In the present study, AChE activity was investigated in different brain areas cerebrum and cerebellum in male and female Rattus norvegicus. Females had a significant increase in AChE activity in cerebrum and cerebellum in comparision with male cerebrum and cerebellum. We 
also found that RNA granules are more in female cerebrum and cerebellum it may be one of the reason that affects the expression of $\mathrm{AChE}$ gene.

It is not possible, at present, to assign a definite factor to explain the pattern of deficit observed in the enzyme activity in male. Among the possibilities, decreased blood flow in brain causing hypoxia has been suggested for decrement in AChE turnover in whole brain of male [48]. Lack of uniformity in profile of AChE activity may be a reflection of functional heterogeneity in central cholinergic system observed by several workers on various parameters [49]. Through this study, we inched closer to clarity on structure and neuronal topography of AChE as shown by the results. In conclusion, the present study has provided a profile of AChE activity in major brain areas cerebrum and cerebellum Rattus norvegicus. The activity in cerebrum and cerebellum indicates a possible pattern of distribution of G4 and G1 molecular forms of AChE in brain areas, respectively. It seems that the G4 form is dominant and is affected by sex as compared to $\mathrm{G} 1$.

\section{CONCLUSION}

The variable enzyme activity in different brain areas and sex related changes observed in male and female Rattus norvegicus might be having an important bearing for functional heterogeneity reported for central cholinergic neuronal system and development of specific pharmacotherapy for cognitive disorders. We anticipate that, this study could lay foundation for future AChE studies in vertebrates and humans enroute to discovering novel therapeutic targets based on AChE metabolism.

\section{Conflicts of Interests: None}

\section{REFERENCES}

[1]. Boell J, Nechmansohn D. Electron microscopic localization of cholinesterase, by a copperleadthio choline technique. J Neurochem 1966;3:1345

[2]. Aldridge WN, Johnson MK. Cholinesterase, succinic dehydrogenase, nucleic acids, esterase and glutathione reductase in subcellular fractions from rat brain. J Biochem 1959;73:270.

[3]. Gerebtzoff MA. Cholinesterases: A histochemical Contribution to the solution of some functional problems. 1959 (Pergemon press, London)1.

[4]. Chacho LW,Cerf JA. Histochemical localization of cholinesterase in the amphibian spinal cord and alterations following ventral root section, J Anat.1960;94:74.

[5]. Hebb C. Cholinergic neurons in vertebrates, Nature (London). 1961;192:527.

[6]. De Robertis E, Pellegraino De Iraldi A, Rodriguez De Lores AG, Salganicoff L. Cholinergic and noncholinergie nerve endings in rat brain. Isolation and subcellular distribution of acetylcholine and acetylcholinesterase. J Neurochem 1962;9:23.

[7]. Lewis PR, Shute CD. Confirmation from choline acetylase analyses of a massive cholinergic innervation to the hippocampus. J Physiol 1964;172:9.

[8]. Shute CCD, Lewis PR.The fine localization of cholinesterase in the hippocampal formation. J Anat 1965;99:938.

[9]. Papp M, Bozsik G. Comparison of the cholinesterase activity in the reticular formation of the lower brain stem of cat \& rabbit. J Neurochem 1966;12:697.

[10]. Bennett EL, Diamond MC, Morimoto H, Herbert M. Acetylcholinesterase activity and weight measures in fifteen brain areas from six lines of rats. J Neurochem 1966;3:563.

[11]. Phillis JW. Acetylcholinesterase in the feline cerebellum. J. Neurochem1968;15:611.

[12]. Tripathi A, Srivastva UC. Histoenzymological distribution of acetylcholinesterase in the cerebral hemispheres of Indian wall lizard, Hemidactylus sflaviviridis. Ann Neuro Sci 2007;14:64.

[13]. Bhasker KS, Joy KP. Acetylcholinesterase positive intrapineal neuronal system in the palm squirrel Funambulus pennati. Biol struct Morphog 1989;2:7.

[14]. Brightman MW, Alberr R.W. Species differences in the distribution of extra neuronal cholinesterase within the vertebrate central nervous system. J. Neurochem 1959;3:244.

[15]. Koelle GB. The histochemical localization of cholinesterases in the central nervous system of the rat. J Comp Neurol 1954;100:211.

[16]. Bon S. Molecular forms of acetylcholinesterase in developing Torpedo embryo, Neuro Chem198; 2(4):577.

[17]. Shen T, Tai, Henchm H, Mc Cammon HA. Molecular dynamics of Acetylcholinesterase, Acc Chem Res 2002;35:332.

[18]. Soreq H, Seidman S. Acetylcholinesterase - new roles for an old actor. Nat Rev Neurosci 2001;2:294.

[19]. Downes GB, Granto M. Acetylcholinesterase function is dispensable for sensary neurite growth but is critical for neuromuscular synapse stability. Dev Biol 2004;270:232.

[20]. Silman I, Sussman JL. Acetylcholinesterase: Classical and nonclassical functions and Pharmacology, Curr opin pharmaco 2005;5:293.

[21]. Talesa V, Grauso M, Arpagaus M, Giovannini E, Romani R. Molecular cloning and expression of a full-length cDNA encoding acetylcholinesterase in optic lobes of the squid Loligo opalescens: a new member of the cholinesterase family resistant to diisopropyl fluorophosphates. J. Neurochem 1999;72:1250. 
[22]. Jones AK, Bentley GN, Parra WG, Agnew A. Molecular characterization of an acetylcholinesterase implicated in the regulation of glucose scavenging by the parasite Schistosoma. The FASEB Journal. 2002 Mar 1;16(3):441-3.

[23]. Zhao P, Zhu K.Y, lang H. Heterologous expression, purification, and biochemical characterization of a greenbug (Schizaphis graminum) acetylcholinesterase encoded by a paralogous gene (ace-1). J Biochem Mol Toxicol 2010;24:51.

[24]. Keyhani E, Maigne J. Acetylcholinesterase in mammalian erythroid cells. J. Cell Sci 1981;52:327.

[25]. Boudinot E, Bernard V, Camp S, Taylor P, Champagnat J. Influence of differential expression of acetylcholinesterase in brain and muscle on respiration. Respir Physiol Neurobiol 2009;165:40.

[26]. Askar KA, Kudi AC, Moody AJ. Purification of Soluble Acetylcholinesterase from Sheep Liver by Affinity Chromatography, Appl Biochem Biotechnol 2011;165:336.

[27]. McKenna OC, Angelakos ET. Acetylcholinesterasecontaining nerve fibers in the canine kidney. Circ Res 1968;23:645.

[28]. El-Bermani AW, Bloomquist El. Acetylcholinesteraseand norepinephrine- containing nerves in developing rat lung. J Embryol Exp Morphol1978;48:177.

[29]. Anguiano GA, Amador A, Moreno-Legorreta ., ArcosOrtega F, Vazquez-Boucard C. Effects of exposure to oxamyl, carbofuran, dichlorvos, and lindane on acetylcholinesterase activity in the gills of the Pacific oyster Crassostrea gigas. Environ Toxicol 2010;25:327.

[30]. Zaitseva OV, Kuznetsova TV. Distribution of acetylcholinesterase activity in the digestive system of the gastropod molluscs Littorina littorea and Achatina fulica. Morfologiia 2008;133:55.

[31]. Hornstein EP, Sambursky DL, Chamberlain SC. Histochemical localization of acetylcholinesterase in the lateral eye and brain of Limulus polyphemus: might acetylcholine be a neurotransmitter for lateral inhibition in the lateral eye ? Vis Neurosci 1994;11:989.

[32]. Arpagaus M, Richier P, Berge Jb, Toutant Jp. Acetylcholinesterases of the nematode Steinernema carpocapsae. The FEBS Journal. 1992 Aug 1;207(3):1101-8.

[33]. Kang JS, Lee DW, Koh YH, Lee SH. A soluble acetylcholinesterase provides chemical defense against xenobiotics in the pinewood nematode. 2001; PLoS One 6: e19063.
[34]. von Wachtendonk D, Neef J. Isolation, purification and molecular properties of an acetylcholinesterase (e.c. 3.1.1.7) from the haemolymph of the sea mussel Mytilus edulis, Comp Biochem Physiol 1978;63:279.

[35]. Steitz TA, Shulman RG. Crystallographic and NMR studies of the serine proteases, Annu Rev Biophys Bioeng 1982;11:419.

[36]. Monnet-Tschudi F, Zurich MG, Schilter B, Costa LG, Honegger P. Maturation-dependent effects of chlorpyrifos and parathion and their oxygen analogs on acetylcholinesterase and neuronal and glial markers in aggregating brain cell cultures. Toxicol Appl Pharmacol 2001;165:175.

[37]. Oron U. Acetylcholinesterase and nerve axon formation during muscle regeneration in rats.Cell Mol Biol1984; 30:411.

[38]. Das UN. Acetylcholinesterase and butyryl cholinesterase as possible markers of low-grade systemic inflammation. Med Sci Monit 2007;13:214.

[39]. Cymborowski B, Skangiel-Kramska J, Dutkowski A. Circadian changes of acetylcholinesterase activity in the brain of house-crickets (Acheta domesticus L). Comp Biochem Physiol 1970;32:367.

[40]. Rybicka K. Emryogenesis in Hymenolepis diminuta V. Acetylcholinesterase in embryos. Exp Parasitol 1967;20:263.

[41]. Seravin LN. Role of Acetylcholinesterase in Water Metabolism of the „,'Dorsal Muscle in Leeches. Dokl Akad Nauk SSSR1965; 160:486.

[42]. Rand JB. Acetylcholine. 2007 WormBook 1.

[43]. Xuereb B, Lefevre E, Garric ., Geffard O. Acetylcholinesterase activity in Gammarus fossarum (Crustacea Amphipoda): linking AChE inhibition and behavioural alteration. Aquat Toxicol 2009;94:114.

[44]. Azevedo-Pereira HM, Lemos MF, Soares AM. Effects of imidacloprid exposure on Chironomus riparius Meigen larvae: linking acetylcholinesterase activity to behavior. Ecotoxicol Environ Saf 2001 ;74:1210.

[45]. Gibson GE, Peterson C, Jenden DJ. Brain acetylcholine synthesis declines with senescence. Science 1981;213:674.

[46]. Silman I, Sussman JL. Structural studies on cholinesterases. In cholinesterases and cholinesterase inhibitors, (Ed) Giacobini E, (Mortin Dunitz, London), 2000:9.

[47]. Reiner PB., Fibiger HC. Functional heterogeneity of central cholinergic system, in Psychopharmacology: The Fourth Generation of Progress (Raven Press Ltd, New York) 1995;147.

How to cite this article:

Rajesh B, Ramesh B, Rajkiran Reddy B, Vimala devi N, Gayathri $\mathrm{KB}$, Bhargav PRK. GENOMICS OF ACETYLCHOLINESTERASE (AChE) ENZYME AND ITS RELATED RNA CONTENT IN THE BRAIN OF RATTUS NORVEGICUS: A PROSPECTIVE STUDY. Int J Anat Res 2017;5(2.1):3676-3681. DOI: 10.16965/ijar.2017.138 